\title{
Pathotypes Characterization and Virulence Diversity of Pseudocercospora griseola the Causal Agent of Angular Leaf Spot Disease Collected from Major Common Bean (Phaseolus vulgaris L.) Growing Areas of Ethiopia
}

\author{
Yayis Rezene ${ }^{1,2^{*}}$, Kassahun Tesfaye ${ }^{2,3}$, Mukankusi Clare ${ }^{4}$ and Paul Gepts ${ }^{5}$ \\ ${ }^{1}$ Molecular Biotech Laboratory, Southern Agricultural Research Institute, Hawassa, Ethiopia \\ ${ }^{2}$ Department of Plant Sciences, University of California, MS 11 Shields Avenue Davis, California, United States of America \\ ${ }^{3}$ Ethiopian Biotechnology Institute, Addis Ababa, Ethiopia \\ ${ }^{4}$ Department of Microbial, Cellular and Molecular Biology, Addis Ababa University, Ethiopia \\ 5International Centre for Tropical Agricultura (CIAT), Kampala, Uganda
}

*Corresponding author: Rezene Y, Molecular Biotech Laboratory, Southern Agricultural Research Institute, Hawassa, Ethiopia, Tel: +251-462206575; E-mail: rezene77@gmail.com

Rec date: July 03, 2018; Acc date: August 23, 2018; Pub date: August 31, 2018

Copyright: (c) 2018 Rezene $\mathrm{Y}$, et al. This is an open-access article distributed under the terms of the creative commons attribution license, which permits unrestricted use, distribution, and reproduction in any medium, provided the original author and source are credited.

\begin{abstract}
Angular leaf spot (ALS) caused by the fungus Pseudocercospora griseola is one of the most economically important disease affecting common bean production in Ethiopia. Until now, no information has been generated regarding the pathotype and pathogenic variability and its distribution in Ethiopia. A study was undertaken to characterize the pathotype and virulence variability among $39 P$. griseola isolates, ALS pathogen, occurring in Ethiopia. A total of 21 pathotypes $(63: 63,63: 59,63: 23,61: 51,56: 36,55: 39,49: 7,48: 60,42: 59,41: 10,34: 53,23: 61$, $19: 33,17: 45,8: 18,8: 0,4: 16,1: 24,1: 10,16: 18$. and $4: 37)$ were determined using 12 sets of ALS common bean differentials cultivars. These results revealed the presence of high and diverse pathogenic variability of the pathogen. Among the determined pathotypes 63:59 and 19:33 were the most frequently appeared. And the occurrence of three pathotypes $(63: 63,63: 59$ and 63:23) were confirmed as well as the previous reports in central America and Argentina. This will be the first comprehensive report of $P$. griseola pathotypes existing in the common bean growing areas of Ethiopia. Except pathotype 8:0 that were compatible with Andean common bean groups, most of the isolates were pathogenic to both Andean and Mesoamerican common bean gene pools. Based on that, the isolates were classified as Mesoamerican origin pathotypes. This specific study provided major information about the pathogenic diversity and determined the pathotype of $P$. griseola from common bean in Ethiopia.
\end{abstract}

Keywords: Pathotype; Pseudocercospora griseola; Pathogenic variability single spore isolates

\section{Introduction}

Common bean (Phaseolus vulgarise L.) is the most important grain legume next to Faba bean and which is produced all of the regions of Ethiopia with different intensity for its nutritional and economic values [1]. Among the common bean diseases, the angular leaf spot (ALS) caused by the fungus Pseudocercospora griseola (Sacc.) Crous and Braun (sin. Phaeoisariopsis griseola (Sacc.) Ferraris) is one of the most important disease [2]. ALS cause necrotic lesions on the aerial parts of the plant, reducing the productivity and quality of common bean seed [3]. Yield loss of more than 374,800 tonnes annually have been reported [4]. The pathogen is found in nature in the form of mycelia or conidia on living tissues of the host plant (susceptible on and offseason crop, volunteer plants), undecomposed infected bean residues and infected soils. The pathogen is a seed born in most cases external contamination may occur on seed during harvesting and the pathogen has been associated with the hilum area of the seed coat [5]. This specific fungus is highly variable and has the ability to infect both Andean and Mesoamerican common bean [6] gene pools. Previous studies have revealed high levels of pathotypic variation in $P$. griseola [7-11]. In addition, many scientists reported the presence of high pathotype diversity of this pathogen. For example, Colombian 33 isolates and Brazilian 27 isolates were classified into 13 pathotypes and 21 pathotypes [8], respectively. In recent studies, high occurrence of pathogenic variability has also been reported in the neighboring Kenyan and Ugandan $[9,10]$. In spite of the high pathotype diversity, all $P$. griseola pathotypes have been divided into Andean and Mesoamerican pathotype groups that correspond to the two common bean gene pools $[7,8,10,11]$. The Andean pathotype group consists of $P$. griseola isolates recovered from large-seeded common bean genotypes of Andean origin that infect Andean genotypes only, the Mesoamerican pathotype group contains isolates that are more virulent on Mesoamerican bean and Andean genotypes [4,7,12,]. To assess the degree of diversity of $P$. griseola isolates, standard methodology for P. griseola pathotype identification [8] which was two sets Andean and Mesoamerican with six common bean genotypes included in each set, were conducted. The common bean differential genotypes and their binary numbers includes, Don Timoteo (1), G1179 (2), Bolon Bayo (4), Montcalm (8), Amendoin (16), G5686 (32), PAN 72 (1), G2858 (2) Flor de Mayo (4), Mexico 54 (8), BAT 332 (16) and Cornell 49242 (32). The number or race designation given to an isolate is determined by the cultivars of the differential set that are infected by that isolate. For example; if an isolate infects Andean common bean genotype Amendoin and Montcalm (binary value, 16 and 8 respectively) and the Mesoamerican variety BAT332 (binary value 16) and Cornell 49242 (32) the race would be designated by adding the 
Citation: Rezene Y, Tesfaye K, Clare M, Gepts P (2018) Pathotypes Characterization and Virulence Diversity of Pseudocercospora griseola the Causal Agent of Angular Leaf Spot Disease Collected from Major Common Bean (Phaseolus vulgaris L.) Growing Areas of Ethiopia. J Plant Pathol Microbiol 9: 445. doi:10.4172/2157-7471.1000445

Page 2 of 6

values (16+8): $(16+32)$ which is $24: 48$ Knowledge of pathotype variation among the isolates of P. griseola is important to the common bean improvement program to guide the deployment of resistance genes to ALS disease. However, there is no information on the Ethiopian $P$. griseola isolates, which puts the common bean improvement program under challenging situation to develop durable disease (ALS) resistance varieties with wider adaptation. Therefore, this specific study used the international sets of ALS differential common bean cultivars to determine and characterize the P. griseola pathotypes occurring in bean growing areas of Ethiopia. The objectives of the study were to determine the pathotype variability and the virulence pattern of $P$. griseola in the bean growing agro-ecologies of Ethiopia and to identify predominant pathotypes that exist in the major common bean growing areas of Ethiopia.

\section{Materials and Methods}

\section{Sampling strategy and collection}

Samples of infected leaves with symptoms of ALS were collected from the fields during survey from 2016 to 2017. They obtained from diverse agro-ecological zones in six diverse areas of Ethiopia (Areka, Dolla, Chano, Omo, Wondo and Goffa). These locations are known for its major common bean production [13] and for its high common bean disease severity especially the ALS. The sampling locations were selected based on the intensity of bean production, special ecological locations representing diverse conditions under which common beans are produced (Figure 1).

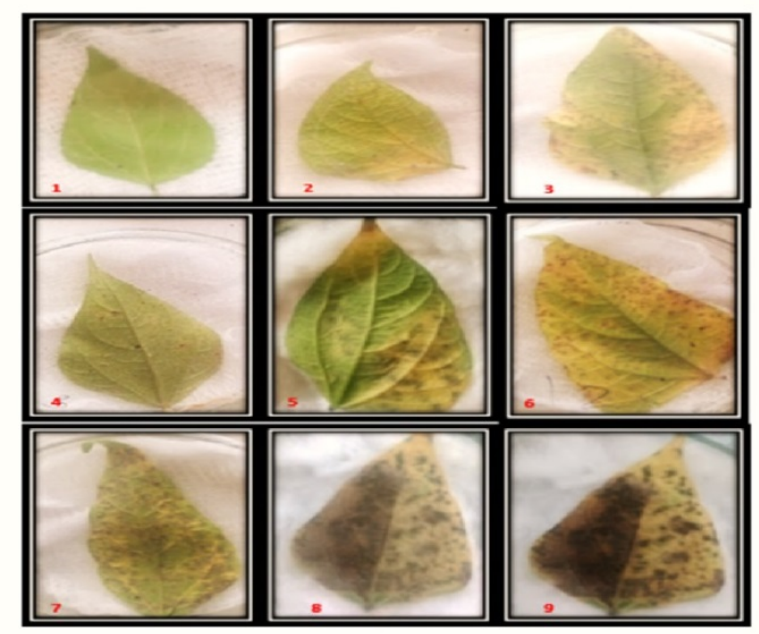

Figure 1: Different disease scoring of leaves inoculated with Pseudocercospora griseola, the causal agents of angular leaf spot disease, using the proposed detached-leaf inoculation method, where $1=$ no visible symptoms; $3=10$ to $20 \%$ of plants infected and/or about $5 \%$ of the total plant area affected by the pathogen; $5=40$ to $50 \%$ of plants infected and/or about $20 \%$ of plant area affected; $7=60$ to $70 \%$ of plants infected and/or about $40 \%$ of plant area affected; and $9=>80 \%$.

Random sampling technique were adopted in which infected leaves with lesion symptoms usually appear as a brown spot with a tan or silvery center that were initially confined to tissue between major veins, that gives angular appearance were collected from 10 random farmers field from each location. Then collected leaf samples were kept in a paper bag and transported to the lab.

\section{$P$. griseola isolation and inoculum preparation}

Selected fresh diseased common bean leaf samples from the collections were directly used and lesions were thereafter examined under a dissecting microscope (Motic BA210) to view the synemata and assess the quality of the sporulation. Conidia of individual lesions were picked from the clean synemata by gently brushing the tips with a small piece of agar at the tip of an inoculating needle and transferred to a drop of sterile water placed on water agar $(2 \%)$ as described by Mahuku et al. [14]. The inoculated petri dishes were allowed to grow the pathogen evenly. The Petri dishes were incubated at $24^{\circ} \mathrm{C}$ for $24 \mathrm{hr}$ and then the germinated spores were picked and immediately transferred to V8 media ( $800 \mathrm{~mL}$ of distilled water, $200 \mathrm{~mL}$ of V8 juice, $3 \mathrm{~g}$ of $\mathrm{CaCO}_{3}$ and $20 \mathrm{~g}$ of agar. Each Petri dishes of V8 was inoculated with single conidia avoiding mixtures during race identification and determination. Each colony that grows from a single conidium was treated as an isolate and a single spore isolates are considered pure during race determination. For the colonies to develop and multiply the Petri-dishes were allowed for about 14 days. Then each colony was treated as monosporic isolate.

\section{Inoculation and pathotype determination}

Isolation, monosporic culture and inoculation were done according to the method developed by Pastor Caralles et al. [12]. Before the inoculation, the spore concentration was adjusted in distil water at 1.0 $\times 10^{5}$ per ml using haemocytometer. Monosporic isolates were grown in petri dishes containing V8 medium. The resulting spores and mycelia were scrapped smoothly with a spatula and filtered through gauze and the spore concentration was adjusted to $2.0 \times 10^{4}$ conidia/mL. Detached leaves of the 12 common bean differential cultivars (Don Timoteo, G 11796, Bolon Bayo, Montcalm, Amendoin, G 5686, Pan 72, G 2858, Flore de mayo, Mexico 54, BAT 332, Cornell 49242), which grown in the screening house, were used for pathotype determination. Detached leaf method was conducted with minor modifications. Eighteen days after germination, the middle follicle of the first trifoliate leaves of each common bean differential plants were removed or detached when they had reached approximately two-thirds of their full development. The detached leaves were inoculated by immersion into a spore suspension and placed in petri dishes $(90 \mathrm{~mm}$ diameter $\times 15 \mathrm{~mm}$ height) on a cotton moistened with $3.0 \mathrm{~mL}$ of tap water. The experiment was replicated three times for consistent result. The petri dishes were watered regularly to maintain about $95 \%$ relative humidity to allow the growth of the pathogen. Disease severity on the inoculated plants was evaluated using 1-9 visual score scale (Schoonhoven and Pastor-Corrales, 1987, Figure 2) for 21 days at an interval of three days. Pathotypes were defined by rating scores of 1-3 to be incompatible (-) or resistant, while ratings $>3$ were compatible $(+)$ or susceptible. Pathotype designation was executed by adding binary values of the differential genotypes that were compatible with the respective $P$. griseola isolates (Table 1 and Figure 1).

\begin{tabular}{|l|l|l|l|l|l|}
\hline Code & Cultivar Id & $\begin{array}{l}\text { Seed } \\
\text { Size }\end{array}$ & Bean Race & $\begin{array}{l}\text { Binary } \\
\text { Value }\end{array}$ & $\begin{array}{l}\text { R Gene } \\
\text { Present }\end{array}$ \\
\hline A & Don Timoteo & Medium & Chile & 1 & 1 dominant \\
\hline B & G 11796 & Large & Peru & 2 & -- \\
\hline
\end{tabular}


Citation: Rezene Y, Tesfaye K, Clare M, Gepts P (2018) Pathotypes Characterization and Virulence Diversity of Pseudocercospora griseola the Causal Agent of Angular Leaf Spot Disease Collected from Major Common Bean (Phaseolus vulgaris L.) Growing Areas of Ethiopia. J Plant Pathol Microbiol 9: 445. doi:10.4172/2157-7471.1000445

Page 3 of 6

\begin{tabular}{|c|c|c|c|c|c|}
\hline C & Bolon Bayo & Large & Peru & 4 & -- \\
\hline D & Montcalm & Large & $\begin{array}{l}\text { Nueva } \\
\text { Granda }\end{array}$ & 8 & 2 recessives \\
\hline $\mathrm{E}$ & Amendoim & Large & $\begin{array}{l}\text { Nueva } \\
\text { Granda }\end{array}$ & 16 & 2 recessives \\
\hline $\mathrm{F}$ & G 5686 & Large & $\begin{array}{l}\text { Nueva } \\
\text { Granda }\end{array}$ & 32 & 1 dominant \\
\hline G & Pan 72 & Small & Mesoamerica & 1 & 1 dominant \\
\hline $\mathrm{H}$ & G 2858 & Medium & Durango & 2 & 1 dominant \\
\hline 1 & $\begin{array}{l}\text { Flore } \quad \text { De } \\
\text { Mayo }\end{array}$ & Small & Jalisco & 4 & 2 duplicates \\
\hline $\mathrm{J}$ & Mexico 54 & Medium & Jalisco & 8 & $\begin{array}{l}\mathrm{Ph}-2, \mathrm{Ph}-5 \\
\mathrm{ph}-6\end{array}$ \\
\hline $\mathrm{K}$ & ВАТ332 & Small & Mesoamerica & 16 & ph- $6^{2}$ \\
\hline $\mathrm{L}$ & $\begin{array}{l}\text { Cornell } \\
49242\end{array}$ & Small & Mesoamerica & 32 & $\mathrm{Ph}-3$ \\
\hline
\end{tabular}

Table 1: Common bean ALS differential cultivar and binary system for pathotype determination study.

\section{Results}

\section{Pathotype diversity and distribution of $P$. griseola isolates from Ethiopia}

We obtained 39 P. griseola isolates from various regions of Ethiopia and designated them as Code Pg01-Pg39 as described in Table 2. This study revealed the existence of 21 P. griseola pathotypes among the 39 isolates occurring in Ethiopia. Most of the isolates showed highly pathogenic on both Andean and Middle American common bean differentials, therefore they were considered as the Middle American pathotype group. This result is in agreement with the fact that Mesoamerican gene pool common bean cultivars predominantly grown in Ethiopia. The remaining few number of isolates were highly pathogenic only on the Andean differentials and these isolates infecting only the Andean differentials were considered members of the Andean pathotype group. Among 21 pathotypes, two pathotypes (63:59 and 19:33) occurred most frequently (Figure 2). Different pathotypes co-exist in certain common bean production areas. Isolates, which were obtained from similar areas or geographic location, varied in their pathogenicity. For example, two isolates coded with $\mathrm{PgO1}$ and $\mathrm{PgO}$ from Areka district induced similar pathogenicity on some of the differentials but not on all the differential genotypes. In most cases, $P$. griseola isolates obtained from the same geographic locations varied in their pathogens confirming presence of pathotype variability in Ethiopian isolates.

\section{Reaction of common bean differentials to $P$. griseola pathogen}

All the international differential sets of common bean genotypes reacted differently for the monosporic $P$. griseola isolates obtained from the diverse common bean growing regions of Ethiopia. The 39 monosporic pure isolates $P$. griseola obtained from the infected leaves

collected from the diverse common bean growing regions of Ethiopia caused lesions of angular leaf spot symptoms in some or all of the host differential host common bean genotypes. Symptoms in the leaves were brown spots that appeared on the primary detached leaves as angular brown spot limited by veins were observed. The fungal growth on the underside of the spots were observed as clusters of synemata which bared pores or conidia. Under the electron microscope, conidian were observed as obclavate cylindrical with two to four septate.

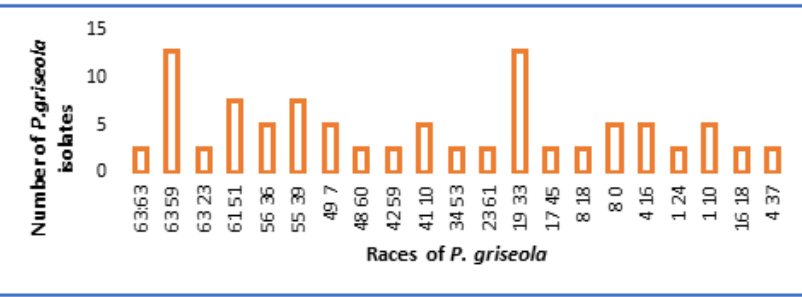

Figure 2: Frequency of Pseudocercospora griseola in Ethiopia.

\section{Virulence analysis and pathotype identification}

During sample collection, ALS was observed in most of the common bean fields. Variations in response of the ALS differentials cultivars were observed irrespective of the gene pool in which they were originated. P. griseola pathotypes are defined based on the pathogenicity reaction to a set of 12 common bean differential genotypes. In this study, the pathogenicity reaction of 39 isolates revealed the existence of pathotype variability in Ethiopian $P$. griseola isolates (Table 2). Based on the virulence reaction, 21 pathotypes were cauterized and all of the pathotypes were virulence to both the Andean and Mesoamerican common bean sets of differentials except pathotype 8:0. The result also confirmed the presence of both Andean and Mesoamerican origin pathotypes in Ethiopia (Table 2).

\begin{tabular}{|l|l|l|l|}
\hline Code & Location & Isolate & Pathotype \\
\hline Pg01 & Areka & PG 37A & $49: 07$ \\
\hline Pg02 & Areka & R7P8 & $63: 59$ \\
\hline Pg03 & Areka & R6P14B & $61: 51$ \\
\hline Pg04 & Gofa & PG44A & $63: 59$ \\
\hline Pg05 & Gofa & PG32C & $34: 53$ \\
\hline Pg06 & Gofa & CD45A & $49: 07$ \\
\hline Pg07 & Gofa & CD50B & $55: 39$ \\
\hline Pg08 & Gofa & CDPG33C & $55: 39$ \\
\hline Pg09 & Omo/Jinka & om418 & $63: 23$ \\
\hline Pg10 & Chano & pg384 & $16: 18$ \\
\hline Pg11 & Wondo & p11 & $23: 61$ \\
\hline Pg12 & Wondo & p67 & $63: 63$ \\
\hline Pg13 & Gofa & PG112 & $63: 59$ \\
\hline
\end{tabular}


Citation: $\quad$ Rezene Y, Tesfaye K, Clare M, Gepts P (2018) Pathotypes Characterization and Virulence Diversity of Pseudocercospora griseola the Causal Agent of Angular Leaf Spot Disease Collected from Major Common Bean (Phaseolus vulgaris L.) Growing Areas of Ethiopia. J Plant Pathol Microbiol 9: 445. doi:10.4172/2157-7471.1000445

Page 4 of 6

\begin{tabular}{|l|l|l|l|}
\hline Pg14 & Areka & R7P8 & $48: 60$ \\
\hline Pg15 & Areka & R1P35 & $63: 59$ \\
\hline Pg16 & Areka & R1P5C & $63: 59$ \\
\hline Pg17 & Areka & R1P8B & $08: 18$ \\
\hline Pg18 & Areka & R1PBA & $17: 45$ \\
\hline Pg19 & Gofa & PG 110 & $4: 37$ \\
\hline Pg20 & Areka & R3P3A & $8: 0$ \\
\hline Pg21 & Areka & R4P2B & $8: 0$ \\
\hline Pg22 & Areka & R1P8C & $4: 16$ \\
\hline Pg23 & Areka & R6P11 & $4: 16$ \\
\hline Pg24 & Wondo & B6P57 & $56: 36$ \\
\hline Pg25 & Wondo & B3P46 & $41: 10$ \\
\hline Pg26 & Wondo & ADP-0095 & $61: 51$ \\
\hline Pg27 & Wondo & B6P57 & $56: 36$ \\
\hline Pg28 & Wondo & ADP-0675 & $41: 10$ \\
\hline Pg29 & Dolla & D 13 & $42: 59$ \\
\hline
\end{tabular}

\begin{tabular}{|l|l|l|l|}
\hline Pg30 & Dolla & B6P14 & $61: 51$ \\
\hline Pg31 & Chano & C D PG32 & $19: 33$ \\
\hline Pg32 & Chano & C D PG38 & $19: 33$ \\
\hline Pg33 & Chano & C D PG38 & $19: 33$ \\
\hline Pg34 & Chano & C DPG 41 & $1: 10$ \\
\hline Pg35 & Chano & C D PG 44 & $1: 24$ \\
\hline Pg36 & Chano & C DPG 45 & $19: 33$ \\
\hline Pg37 & Chano & C D PG46 & $41: 10$ \\
\hline Pg38 & Chano & C D PG 50 & $55: 39$ \\
\hline Pg39 & Chano & C D PG50 & $19: 33$ \\
\hline
\end{tabular}

Table 2: Pathotype determination Pseudocercospora griseola from diverse common bean growing areas of Ethiopia.

The study identified the isolate, which is compatible to all of the 12 sets of differential common bean genotypes, as pathotype 63:63 (Table 3). Pathotype 63:63 overcomes resistance genes in 12 known sources of resistance that constitute differential of sets.

\begin{tabular}{|c|c|c|c|c|c|c|c|c|c|c|c|c|c|}
\hline \multicolumn{6}{|c|}{ Andean } & \multicolumn{6}{|c|}{ Mesoamerican } & \multirow[t]{3}{*}{ Pathotype } & \multirow[t]{3}{*}{ No of Isolates } \\
\hline $\mathbf{a}$ & b & c & d & e & $f$ & g & h & $\mathbf{i}$ & j & k & 1 & & \\
\hline 1 & 2 & 4 & 8 & 16 & 32 & 1 & 2 & 4 & 8 & 16 & 32 & & \\
\hline+ & + & + & + & + & + & + & + & + & + & + & + & 63:63 & 1 \\
\hline+ & + & + & + & + & + & + & + & - & + & + & + & $63: 59$ & 5 \\
\hline+ & + & + & + & + & + & + & + & + & - & + & - & $63: 23$ & 1 \\
\hline+ & - & + & + & + & + & + & + & - & - & - & + & $61: 51$ & 3 \\
\hline- & - & - & + & + & + & - & - & + & - & - & + & $56: 36$ & 2 \\
\hline+ & + & + & - & + & + & + & - & + & - & - & + & $55: 39$ & 3 \\
\hline+ & - & - & - & + & + & + & + & + & - & - & + & 49:07 & 2 \\
\hline - & - & - & - & + & + & - & - & + & + & + & + & 48:60 & 1 \\
\hline- & + & - & + & - & + & + & + & - & + & + & + & 42:59 & 1 \\
\hline+ & - & - & + & - & + & - & + & - & + & - & - & 41:10 & 2 \\
\hline- & + & - & - & - & + & + & - & + & - & + & + & $34: 53$ & 1 \\
\hline+ & + & + & - & + & - & + & - & + & + & + & + & $23: 61$ & 1 \\
\hline+ & + & - & - & + & - & + & - & + & - & - & + & 19:33 & 5 \\
\hline+ & - & - & - & + & - & + & - & + & + & - & + & $17: 45$ & 1 \\
\hline - & - & - & + & - & - & - & + & - & - & + & - & 08:18 & 1 \\
\hline- & - & - & + & - & - & - & - & - & - & - & - & 08:00 & 2 \\
\hline- & - & + & - & - & - & - & - & - & - & + & - & $04: 16$ & 2 \\
\hline
\end{tabular}


Citation: Rezene Y, Tesfaye K, Clare M, Gepts P (2018) Pathotypes Characterization and Virulence Diversity of Pseudocercospora griseola the Causal Agent of Angular Leaf Spot Disease Collected from Major Common Bean (Phaseolus vulgaris L.) Growing Areas of Ethiopia. J Plant Pathol Microbiol 9: 445. doi:10.4172/2157-7471.1000445

Page 5 of 6

\begin{tabular}{|c|c|c|c|c|c|c|c|c|c|c|c|c|c|}
\hline+ & - & - & - & - & - & - & - & - & + & + & - & $01: 24$ & 1 \\
\hline+ & - & - & - & - & - & - & + & - & + & - & - & $01: 10$ & 2 \\
\hline- & - & - & - & + & - & + & - & + & - & - & - & $16: 18$ & 1 \\
\hline- & - & + & - & - & - & + & - & + & - & - & + & $04: 37$ & 1 \\
\hline \multicolumn{13}{|c|}{ Total } & 39 \\
\hline
\end{tabular}

Table 3: Pathotype identification and reaction of differential common bean genotypes to the 39 isolates of $P$. griseola collected from diverse common bean growing areas of Ethiopia.

\section{Race distribution and frequency of occurrence}

The race and frequency distribution of Ethiopian P. griseola isolates were analysed as percentages from the total number of isolates and the results are presented in Figure 3.

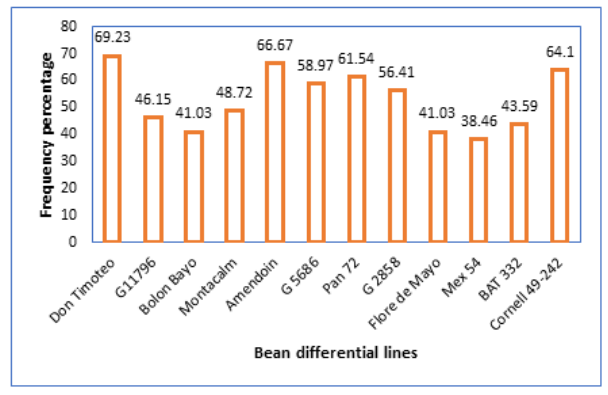

Figure 3: Frequency (\%) of compatible reaction between sets of differential common bean genotypes and evaluated isolates.

A wide frequency variation revealed in which differential 'cultivar Mexico-54' had the lowest frequency with $38.47 \%$ while cultivars Don Timoteo (69.23\%) and Amendoin (66.67\%) scored the highest. The number of isolates obtained from the Middle American genotypes were greater than those from the Andean genotype. This result was in lines with the dominantly common bean production in Ethiopia is from the Middle America group and since the P. griseola were coevolved with common bean gene pool.

\section{Discussion}

This study revealed that the presence of both Andean and Mesoamerican pathotypes in Ethiopia whereas the Mesoamerican pathotype was more predominant than Andean pathotype. This result supports that Mesoamerican common bean genotypes were dominantly cultivated in Ethiopia [15]. Although, no sexual reproduction was confirmed the $P$. griseola isolates from the diverse common bean growing regions showed high variation in virulence pattern. The virulence variation was high in such way that isolates collected from the same location showed differences in their virulence patterns. Several different isolates found in the same farm is not surprising. These results are in agreement with the findings of PastorCorrales et al., Busogoro et al. and Wagara et al. [8,9]. This result was also supported by many authors in the other countries such as Mexico, Brazil, Kenya, Uganda and Tanzania $[9,10,16,17]$. The high difference in virulence patterns observed during the study indicates that the majority of the resistance genes in the host differentials common bean cultivars were effective against most of the P. griseola isolates from Ethiopia. This might suggest $P$. griseola isolates from Ethiopia probably have isolates with different virulence genes which might not matched with the resistance genes in the host differentials common bean cultivars. This is new report of virulence pattern of $P$. griseola isolates from the common bean growing areas of Ethiopia that includes 21 pathotypes. Among them, pathotypes 63:59 and 19:33, newly designated in this study were the most frequently observed. The majority of common bean cultivars have shown sever infections of P. griseola, confirming the existence of new pathotype of P. griseola. However, the sources of new race are currently not known and it might probably farmers practice in adjacent field. The informal seed exchange, which is dominant seed system in Ethiopian farming community, may lead to the introduction of new pathotypes and the pathotype variability. As many of the reports, the pathogen might have undergone Para sexual that facilitates exchange of genetic material within and between isolates. It might also because of chromosomal inversion, deletion and presence of transposons because all are reported to have capability to increase the variability in $P$. griseola [18-20]. Mexico-54 with low frequency percentage of pathogen infection could be used as parental lines with potential source of resistance gene in the common bean breeding program.

\section{Conclusion}

This specific study revealed the existence of virulence diversity of $P$. griseola, pathogen of common bean ALS in Ethiopia. The isolates were most predominantly from the Middle American pathotype gene pool that affects mostly both common bean gene pools of Middle American and Andean. This is in lines with the dominantly grown common bean type (the middle American gene pool) in Ethiopia. From the study, it was determined that the existence of large pathogenic and pathotype variability of $P$. griseola isolates and these pathotypes were distributed across diverse regions of Ethiopia. P. griseola isolates, which were obtained from the same geographic locations, showed different pathogenicity due to the district differences in response common bean differential genotypes. Hence, this would be the first report of virulence variation of Ethiopian isolates and the result from this study confirmed the presence of high pathotype in Ethiopia. The information generated from this study has a significant implication for the bean improvement program, because the $P$. griseola isolates existing in Ethiopia are with wider virulence spectrum. Hence these pathogens must be taken into consideration when developing and deploying bean cultivars with resistance to ALS. Hence the common bean breeding 
Citation: Rezene Y, Tesfaye K, Clare M, Gepts P (2018) Pathotypes Characterization and Virulence Diversity of Pseudocercospora griseola the Causal Agent of Angular Leaf Spot Disease Collected from Major Common Bean (Phaseolus vulgaris L.) Growing Areas of Ethiopia. J Plant Pathol Microbiol 9: 445. doi:10.4172/2157-7471.1000445

Page 6 of 6

program could plan at developing bean cultivars with non-pathotype specific or non-race specific resistance.

\section{Conflict of Interest}

The authors declare that they have no conflict of interest

\section{Acknowledgments}

This paper serves in part of the completion of a $\mathrm{PhD}$ dissertation of the first author (Yayis Rezene), which is carried out as part of the African Bean Consortium (ABC) project. The authors acknowledge the funding, support and provision of molecular lab facilities by the KIRKHOUSE TRUST. We also extend our thanks to the Southern Agricultural Research Institute (SARI), Centro Internacional de Agricultura Tropical (CIAT), and the African Bean Consortium ABC partner countries.

\section{References}

1. Central Statistics Agency of Ethiopia (2016) Report on area and crop production of major crops for 2016 Meher season, Addis Ababa, Ethiopia 1: 125.

2. Tadesse N, Ahmed S, Gorfu D, Beshir T, Fininsa C, et al. (2006) Review of research on diseases food legumes. Increasing Crop Production through Improved Plant Protection 1: 85.

3. Singh SP, Schwartz HF (2010) Breeding common bean for resistance to diseases: A review. Crop Science 50: 2199-2223.

4. Wortmann CS (1998) Atlas of common bean (Phaseolus vulgaris L.) production in Africa, CIAT.

5. Correa-Victoria FJ, Pastor-Corrales MA, Saettler AW (1989) Angular leaf spot. Bean Production Problems in the Tropics 59: 75.

6. Liebenberg MM, Pretorius ZA (1997) A review of angular leaf spot of common bean (Phaseolus vulgaris L.) African Plant Protection 3: 81-106.

7. Guzmán P, Gilbertson RL, Nodari R, Johnson WC, Temple, SR, et al (1995) Characterization of variability in the fungus Phaeoisariopsis griseola suggests coevolution with the common bean (Phaseolus vulgaris). Phytopathology 85: 600-607.

8. Pastor-Corrales MA, Jara C, Singh SP (1998) Pathogenic variation in, sources of, and breeding for resistance to Phaeoisariopsis griseola causing angular leaf spot in common bean. Euphytica 103: 161-171.
9. Wagara IN, Mwang'ombe AW, Kimenju JW, Buruchara RA (2005) Virulence, variability and physiological races of the angular leaf spot pathogen Phaeoisariopsis griseola in Kenya. African Plant Protection 11: 23-31.

10. Ddamulira G, Mukankusi C, Ochwo-Ssemakula M, Edema R, Sseruwagi P, et al. (2014) Distribution and variability of Pseudocercospora griseola in Uganda. Journal of Agricultural Science 6: 16.

11. Chilagane LA, Nchimbi-Msolla S, Kusolwa PM, Porch TG, Diaz LMS, et al. (2016) Characterization of the common bean host and Pseudocercospora griseola, the causative agent of angular leaf spot disease in Tanzania. African Journal of Plant Science 10: 238-245.

12. Pastor-Corrales MA (2004) Review of coevolution studies between pathogens and their common bean hosts: Implication for the development of disease-resistant beans. Annual Report-Bean Improvement Cooperative 47: 67-68.

13. Allen DJ, Dessert M, Trutmann P, Voss J (1989) Common beans in Africa and their constraints. Bean production problems in the tropics. CIAT, Cali, Colombia pp: 9-31.

14. Mahuku GS, Jara C, Cuasquer JB, Castellanos G (2002) Genetic variability within Phaeoisariopsis griseola from Central America and its implications for resistance breeding of common bean. Plant pathology 51: 594-604.

15. Asfaw A, Blair MW, Almekinders C (2009) Genetic diversity and population structure of common bean (Phaseolus vulgaris L.) landraces from the East African highlands. Theoretical and Applied Genetics 120: $1-12$.

16. Mahuku GS, Iglesias ÁM, Jara C (2009) Genetics of angular leaf spot resistance in the Andean common bean accession G5686 and identification of markers linked to the resistance genes. Euphytica 167: 381-396.

17. Castellamos G, Jara C, Mosquera G (2016) Bean pathogens: Practical guide for Lab and greenhouse work.

18. Kistler HC, Miao VP (1992) New modes of genetic change in filamentous fungi. Annual review of phytopathology 30: 131-153.

19. Kempken F, Kück U (1998) Transposons in filamentous fungi facts and perspectives. BioEssays 20: 652-659.

20. Leung H, Nelson RJ, Leach JE (1993) Population structure of plant pathogenic fungi and bacteria. Advances in Plant Pathology 2: 1. 